\title{
Total internal and external ophthalmoplegia as presenting symptoms of Miller Fisher syndrome
}

\author{
Bik Ling Man
}

Department of Medicine and Geriatrics, Tuen Mun Hospital, Hong Kong, Hong Kong

\section{Correspondence to} Dr Bik Ling Man, beli_man@yahoo.com

Accepted 24 July 2014
To cite: Man BL. BMJ Case Rep Published online:

[please include Day Month Year] doi:10.1136/bcr-2014205554

\section{DESCRIPTION}

A 46-year-old woman, who enjoyed good past health, presented with progressive diplopia and unsteady gait after a recent upper respiratory tract infection. She had no fever and denied use of any cycloplegic drugs. Physical examination showed bilateral ptosis (figure 1), and total external (video 1) and internal ophthalmoplegia (video 2). She had bilateral facial weakness and ataxia of limbs. Her limb power was full and there was generalised hyporeflexia. Cerebrospinal fluid examinations showed white cell count $<1 / \mathrm{mm}^{3}(<5)$, protein $0.28 \mathrm{~g} / \mathrm{L}(0.15-0.4)$, glucose $4.3 \mathrm{mmol} / \mathrm{L}$ (2.2-3.9). Serum anti-GQ1b $\operatorname{IgM}$ and $\operatorname{IgG}$ were strongly positive. MRI of the brain and whole spine were normal. NCT and EEG were normal. She was diagnosed to have Miller Fisher syndrome and was treated with a course of intravenous immunoglobulin. Her ophthalmoplegia improved markedly after treatment.

The GQ1b ganglioside is highly enriched in oculomotor, trochlear and abducens nerves, and the ciliary ganglia. ${ }^{1}$ Postganglionic involvement of the parasympathetic nerve is associated with internal ophthalmoplegia in anti-GQ1b antibody syndrome. ${ }^{2}$ Internal and external ophthalmoplegia is common in anti-GQ1b antibody syndrome ${ }^{3}$ and it should be considered in the differential diagnosis of acute or subacute ophthalmoplegia to allow prompt diagnosis and treatment.

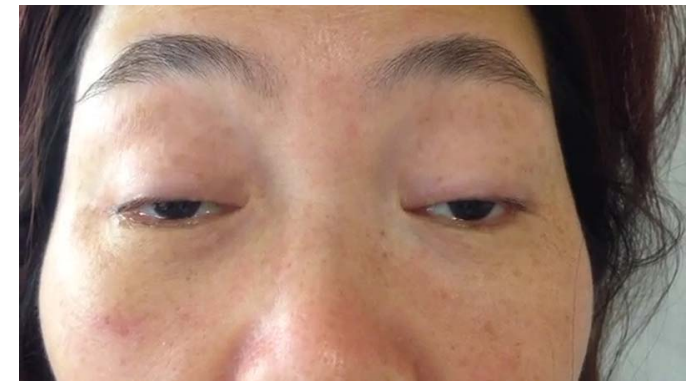

Video 1 Total external ophthalmoplegia.

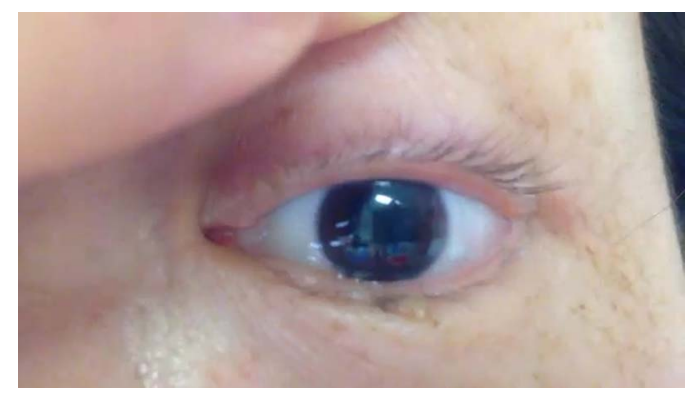

Video 2 Total internal ophthalmoplegia.

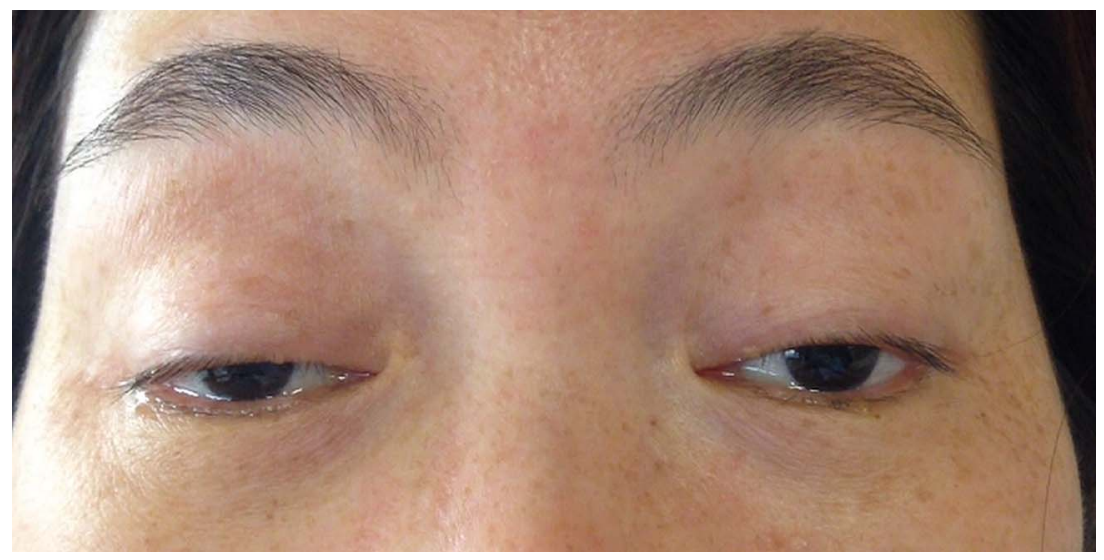

Figure 1 Bilateral ptosis. 


\section{Learning points}

- The GQ1b ganglioside is highly enriched in oculomotor, trochlear and abducens nerves and the ciliary ganglia.

- Postganglionic involvement of the parasympathetic nerve is associated with internal ophthalmoplegia in anti-GQ1b antibody syndrome.

- Internal and external ophthalmoplegia is common in anti-GQ1b antibody syndrome and it should be considered in the differential diagnosis of acute or subacute ophthalmoplegia.
Competing interests None.

Patient consent Obtained.

Provenance and peer review Not commissioned; externally peer reviewed.

\section{REFERENCES}

1 Chiba A, Kusunoki S, Obata $\mathrm{H}$, et al. Serum anti-GQ1b IgG antibody is associated with ophthalmoplegia in Miller Fisher syndrome and Guillain-Barre syndrome: clinical and immunohistochemical studies. Neurology 1993:43:1911-17.

2 Sugita A, Yanagisawa T, Kamo T, et al. Internal ophthalmoplegia with anti-GQ1b IgG antibody. J Neurol 2002:249:1475-6.

3 Lee SH, Lim GH, Kim JS, et al. Acute ophthalmoplegia (without ataxia) associated with anti-GQ1b antibody. Neurology 2008;71:426-9.

Copyright 2014 BMJ Publishing Group. All rights reserved. For permission to reuse any of this content visit http://group.bmj.com/group/rights-licensing/permissions.

BMJ Case Report Fellows may re-use this article for personal use and teaching without any further permission.

Become a Fellow of BMJ Case Reports today and you can:

- Submit as many cases as you like

- Enjoy fast sympathetic peer review and rapid publication of accepted articles

- Access all the published articles

- Re-use any of the published material for personal use and teaching without further permission

For information on Institutional Fellowships contact consortiasales@bmjgroup.com

Visit casereports.bmj.com for more articles like this and to become a Fellow 